\title{
RANCANGAN MARKETPLACE HEWAN TERNAK APPLICATION
}

\author{
Fitria Mitha Firnanda ${ }^{\varpi}$, Diki Kusumah \\ Program Studi Manajemen Informatika, Politeknik Pos Indonesia, Bandung, Indonesia \\ Email: fymthaa08@gmail.com
}

DOI: $\underline{\text { htps://doi.org/10.46880/jmika.Vol4No2.pp126-133 }}$

\begin{abstract}
Marketplace of livestock is engaged in the business of selling and purchasing which broadly has the activities of selling and purchasing animals. Usually have several system admins who work and control an application system by handling also the development of businessmen in the application, including making reports and managing master data. In this study business process observations were made from observations of free-range applications which have become a unique marketplace specifically for livestock. The business process that is happening right now, that an application provides a place for various pet shops to pour their sales business activities in accordance with the dimensions of the animals they sell, on the other hand also receives intensive care services for animal development for farmers. It takes a long time for a common marketplace application to get a service maintenance partner, and time brackets along with maintenance service wages that are proportional to the value of feed prices, an increase in the amount of food, and season conditions for a sales activity there is no precise analysis. Based on the needs of this matter, a design of a new market place application design is needed which is equivalent to a market place in general, which only has the ability to sell and purchase. In the analysis phase of modeling using Business Process Modeling Notation (BPMN), while the design stage uses Unified Modeling Language (UML). The design of this application will be a guideline in implementing software in future research.
\end{abstract}

Keyword: Application, Design, Logistic, BPMN, UML.

\begin{abstract}
ABSTRAK
Marketplace hewan ternak bergerak di bidang bisnis penjualan dan pembelian yang secara garis besar memiliki kegiatan penjualan dan pembelian hewan. Biasanya memiliki beberapa admin sistem yang bekerja dan mengendalikan suatu sistem aplikasi dengan menangani pula pengembangan para pembisnis di dalam aplikasi tersebut, termasuk membuat laporan dan mengelola data master. Dalam penelitian ini pengamatan proses bisnis dilakukan dari pengamatan aplikasi angon yang sudah menjadi sebuah unique marketplace khusus hewan ternak. Proses bisnis yang terjadi saat ini, bahwa sebuah aplikasi menyediakan sebuah tempat berbagai toko hewan untuk menuangkan aktivitas bisnis penjualannya sesuai dengan dimensi hewan yang dijualnya, disisi lain juga menerima perawatan intensif jasa untuk perkembangan hewan bagi peternak. Butuh waktu lama bagi sebuah aplikasi marketplace yang umum untuk mendapatkan mitra perawatan jasa, dan waktu kurung beserta upah jasa perawatan yang sebanding dengan nilai harga pakan ,kenaikan jumlah pangan, dan kondisi musim untuk sebuah aktivitas penjualan tidak ada analisis yang tepat. Berdasarkan kebutuhan dari hal ini, diperlukan desain pembuatan rancangan baru aplikasi market place hewan ternak yang setara dengan layaknya marketplace pada umumnya, dimana hanya memiliki kemampuan untuk penjualan dan pembelian saja. Dalam tahapan analisis pemodelan menggunakan Business Process Modeling Notation (BPMN), sedangkan tahapan perancangan menggunakan Unified Modeling Language (UML). Desain aplikasi ini akan menjadi pedoman dalam mengimplementasikan perangkat lunak pada penelitian selanjutnya.
\end{abstract}

Kata Kunci: Aplikasi, Rancangan, Logistik, BPMN, UML.

\section{PENDAHULUAN}

Pada saat ini marketplace di Indonesia dalam menjalankan bisnisnya, telah memberikan layanan kepada pembeli dalam bidang transaction, packaging dan transporting. Dengan target untuk mendapatkan omset yang lebih maka toko penjualan merasa perlu melakukan strategi yang jitu untuk dapat meraih pendapatan sesuai dengan target yang telah ditetapkan (Hafidh, 2020). Berdasarkan penelitian terdahulu, terdapat tiga prioritas kebutuhan pembeli yaitu pengiriman yang mudah dan tepat waktu, pelayanan yang cepat dan pengiriman yang aman (Donoriyanto, 
2010). Penelitian penerapan konsep $C$ to $C$ dalam pembuatan marketplace penjualan kerajinan tangan mempermudah pembeli dan penjual dalam melakukan transaksi jual beli secara online (Hutabarat, Sarkis, \& Manurung, 2018), hal yang sama juga didapatkan pada aplikasi marketplace khas batak berbasis android (Hutauruk, Naibaho, \& Rumahorbo, 2017). Sedangkan hasil penelitian lainnya menyebutkan tentang kebutuhan perancanaan transaction dan packaging yang matang maka akan meminimkan resiko permasalahan penjadwalan dan transportasi (Rusdiana, 2014).

Beberapa langkah strategis yang ditempuh untuk dapat memberikan solusi total bagi pembelinya dalam memberikan layanan penjualan, maka toko melakukan strategi differensiasi. Dilihat dari kegiatannya, marketplace meliputi kegiatan seperti pengemasan (packaging), transaksi (transaction), transportasi barang (freigh transportation), dan pengelolaan pesanan (sales order processing) (Solusi E-Commerce, 2019).

Pada proses bisnis yang terjadi saat ini, para penjual yang sudah terdaftar di aplikasi ini akan menyediakan layanan transportasi juga bagi pengiriman hewan sesuai dengan dimensi jenis, ukuran dan berat hewan. Penjual memerlukan waktu yang lama untuk menyeleksi vendor baru dalam setiap berbagai lokasi. Berdasarkan kebutuhan tersebut maka diperlukan sebuah toko penjual untuk rancangan aplikasi marketplace yang memiliki kemampuan fungsional untuk mengelola penjualan dan pembelian meliputi transaksi dan pengiriman. Dengan dibangunnya sebuah aplikasi marketplace hewan ternak sehingga memperoleh manfaat salah satunya adalah peningkatan dalam rantai pasok, contohnya tempat, waktu dalam proses pengiriman serta produksi dimana hal-hal salah dapat terjadi yang berkaitan erat dengan kualitas hewan sehingga mempermudah proses analisis monitoring dan menjamin sebuah sistem untuk menghasilkan kualitas yang konstan (Pateman, Cahoon, \& Chen, 2016).

Tujuan dari penelitian adalah teridentifikasinya aplikasi marketplace yang dapat digunakan sebagai basis rancangan aplikasi beserta analisis manfaatnya dan rumusan spesifikasi kebutuhan perangkat lunak serta dokumen perancangan aplikasi Marketplace. Penerapan rancangan Aplikasi Marketplace hewan ternak sebagai hasil penelitian memiliki peluang kontribusi. Sebagai kontribusi pengetahuan, rancangan Aplikasi Marketplace hewan ternak didasari dari usulan model sistem informasi, arsitektur aplikasi dan dokumentasi kebutuhan fungsional yang formal. Dan sebagai kontribusi praktis, penerapan teknologi memberikan kontribusi berupa arsitektur aplikasi yang dapat dijadikan arahan merealisasikan aplikasi dengan menerapkan rancangan teknologi informasi. Lebih lanjut hasil dari penelitian dapat dijadikan basis perencanaan untuk pengembangan pangkalan rancangan aplikasi marketplace hewan ternak peneliti lain yang relevan dengan penelitian yang dilakukan.

\section{METODE PENELITIAN}

Metode penelitian yang dilakukan pada penelitian ini seperti terlihat pada gambar berikut:

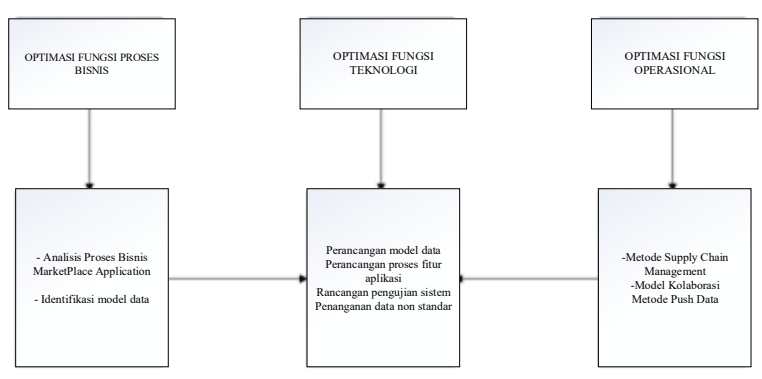

Gambar 1. Metode Penelitian Marketplace Hewan Ternak Application

Tahap penelitian dilakukan dari mulai perumusan optimasi fungsi proses bisnis, optimasi fungsi teknologi dan optimasi fungsi operasional (Supratman, 2014).

\section{Fungsi Proses Bisnis}

Studi literatur dilakukan untuk mendapatkan teori atau konsep, model maupun komponen yang relevan dengan masalah penelitian beserta metodologinya, termasuk best pratices yang telah dilakukan oleh industri tipikal. Tahap ini dilakukan untuk mendapatkan informasi tentang komponenkomponen yang perlu dirumuskan dalam membuat kolaborasi data dan penentuan harga. Berdasarkan studi pendahuluan dan studi literatur yang dilakukan maka dapat diperoleh gambaran variabel yang diperlukan dalam penelitian ini. Studi pendahuluan dilakukan pada marketplace sebelumnya dan pembuatan kuesioner.

\section{Fungsi Teknologi}

Optimasi fungsi teknologi dilakukan dengan pendekatan mempelajari seluruh fungsi/fitur dan cara kerja dari setiap fungsi/komponen perangkat lunak yang sudah dimiliki oleh aplikasi marketplace sebelumnya dan memilih untuk dikolaborasikan/ disinergikan menjadi solusi yang tepat dan sesuai dengan kondisi dan kebutuhan. Dengan metode pemeriksaan tersebut akan dapat diketahui secara pasti kinerja dari setiap fungsi tersebut apakah sudah sesuai dengan kriteria kebutuhan MarketPlace Hewan Ternak 
Application.

Sebagai landasan untuk penelitian berikutnya maka pada fase ini pun didefinisikan dataflow diagram dan entity relationship diagram yang berasal dari fungsi proses bisnis yang dilakukan.

\section{Fungsi Operasional}

Optimasi fungsi operasional memberikan hasil sebagai masukan ke fase optimasi fungsi teknologi berupa metode push data yang dapat dilakukan vendor lokasi maupun toko penjual di marketplace serta cara konsolidasi data bisnisnya.

\section{PERANCANGAN SISTEM}

\section{Analisis Sistem}

Beberapa tips untuk melakukan proses freight forwarder adalah menentukan kebutuhan secara keseluruhan, misal menentukan jumlah total biaya, bukan hanya biaya transortasi saja. Kemudian tentukan skala bisnis mitra dan vendor yang diajak berkolaborasi serta dukungan bisnisnya seperti sumber daya manusia, teknologi informasi dan kebutuhan pelaporannya. Proses bisnis yang terjadi saat ini, para vendor lokasi yang sudah terdaftar di setiap toko akan menyediakan layanan transportasi bagi pengiriman barang milik pembeli ,sesuai dengan dimensi jenis, ukuran dan berat hewan yang sudah dibongkar muat. Pada analisis proses bisnis digunakan analisis rantai nilai dari Porter (Barnes, 2001).

Analisis rantai nilai (value chain analysis) adalah proses di mana sebuah perusahaan atau organisasi mengidentifikasi kegiatan utama dan pendukung yang menambah nilai produk, kemudian menganalisisnya untuk mengurangi biaya atau meningkatkan diferensiasi. Analisis rantai merupakan strategi yang digunakan untuk mengalisis kegiatan internal organisasi. Dengan kata lain, dengan melihat ke dalam kegiatan internal, analisis itu mengungkap di mana keunggulan kompetitif beserta kekurangannya (Pangestu, 2019). Ketika sebuah toko mampu memproduksi hewan dengan biaya yang lebih rendah dari harga pasar atau untuk memberikan hewan-hewan unggulan, ia memperoleh keuntungan. Rantai ini didefinisikan sebagai sekumpulan aktivitas bisnis dimana disetiap tahapan/langkah dalam aktivitas bisnis tersebut menambahkan nilai atau manfaat terhadap barang dan jasa organisasi yang bersangkutan. Jadi analisis rantai nilai Porter diadaptasi untuk menganalisis aktivitas spesifik dari marketplace hewan ternak application sehingga dapat diketahui aktivitas utama dan aktivitas pendukungnya dengan tujuan akhirnya mendapatkan proses bisnis yang lebih efisien (Porter, 1985).
Rantai nilai dari marketplace hewan ternak application dapat dilihat pada gambar 2 berikut:

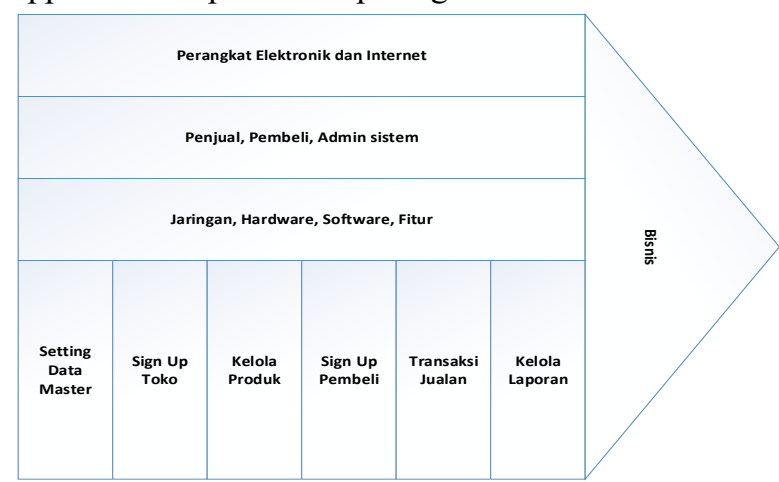

Sumber: (Saraswati, Baihaqi, \& Anggrahini, 2017)

Gambar 2. Value Chain Marketplace Hewan Ternak Application

Rantai nilai pada gambar 2 diatas memiliki jenis aktivitas sebagai berikut :

Aktivitas Utama

1. Setting Data Master

Mengelola semua aktivitas data admin di dalam sistem, melihat postingan hewan, mengelola perbaruan toko yang baru terdaftar di sistem .

2. Sign Up Toko

Dalam hal ini adalah saat penjualan ingin bergabung dalam penjualan hewan dan membuat akun toko ,maka penjual diharuskan sign up terlebih dahulu untuk mendapatkan akses masuk berupa akun di dalam sistem.

3. Kelola Hewan

Selanjutnya, setelah penjual mendapatkan akses masuk .Penjual dapat mengelola hewan dengan melakukan aktivitas tambah data hewan, edit data hewan, dan hapus data hewan.

4. Sign Up Pembeli

Proses ini hanya melibatkan seorang pembeli yang ingin memiliki akun di dalam aplikasi.

5. Transaksi Jual

Proses ini melibatkan penjual dan pembeli yang akan menerima tagihan pembayaran hewan dan pengiriman.

6. Kelola Laporan

Proses ini melibatkan Admin sistem yang akan mengelola semua laporan berikut aktivitas penjualan dan pembelian di dalam sistem, maupun transaksi dan detail.

\section{Aktivitas Pendukung}

1. Perangkat Elektronik dan Internet

Penggunaan teknologi informasi dan komunikasi akan dapat dilakukan perbaikan secara signifikan dalam akses in-transit inventory dan status kedatangan kiriman barang secara akurat baik 
lokasi maupun waktu pengirimannya (delivery time).

2. Penjual, Pembeli, Admin Sistem

Semua Aktor atau User yang terlibat di dalam aktivitas sistem.

3. Jaringan, Hardware, Software, Fitur

Kelengkapan yang ada untuk mendukung penggunaan elektronik dan internet, fungsinya agar lajur sistem aplikasi dapat berjalan.

Margin

Hasil yang didapatkan dari aktivitas utama dan aktivitas pendukung dari proses bisnis yang sedang berjalan di aplikasi market place adalah dapat melakukan aktivitas penjualan dan pembelian sebagai mana mestinya dan memiliki mutu yang lebih baik.

Uraian tugas dari masing-masing jabatan yang terkait dengan sistem informasi dan pengecekan kesesuaian pembagian tugas dengan prinsip-prinsip pengendalian internal adalah sebagai berikut:

1. Admin Sistem
Admin Sistem bertugas meninjau berjalannya sistem di dalam aplikasi dan memberi persetujuan layak atau tidak suatu akun toko untuk melakukan kegiatan bisnisnya di dalam aplikasi.

2. Penjual

Penjual betugas menentukan harga dalam setiap hewan dan melakukan layanan yang pengiriman maupun transaksi dan bertanggung jawab atas berjalannya stok pemesanan.

3. Pembeli

Pembeli bertugas memberi nilai pada suatu produk yang telah diterima.

Untuk menggambarkan proses bisnis yang ada digunakan business process modeling notation (BPMN), untuk memodelkan proses pada sistem sedang berjalan yaitu pada proses bisnis jual beli marketplace berdasarkan setting data master, sign up toko, kelola produk, sign up pembeli, transaksi jual, dan kelola laporan. Adapun kegiatan yang terjadi dalam penilaian transaksi jual di dalam marketplace application digambarkan pada gambar 3.

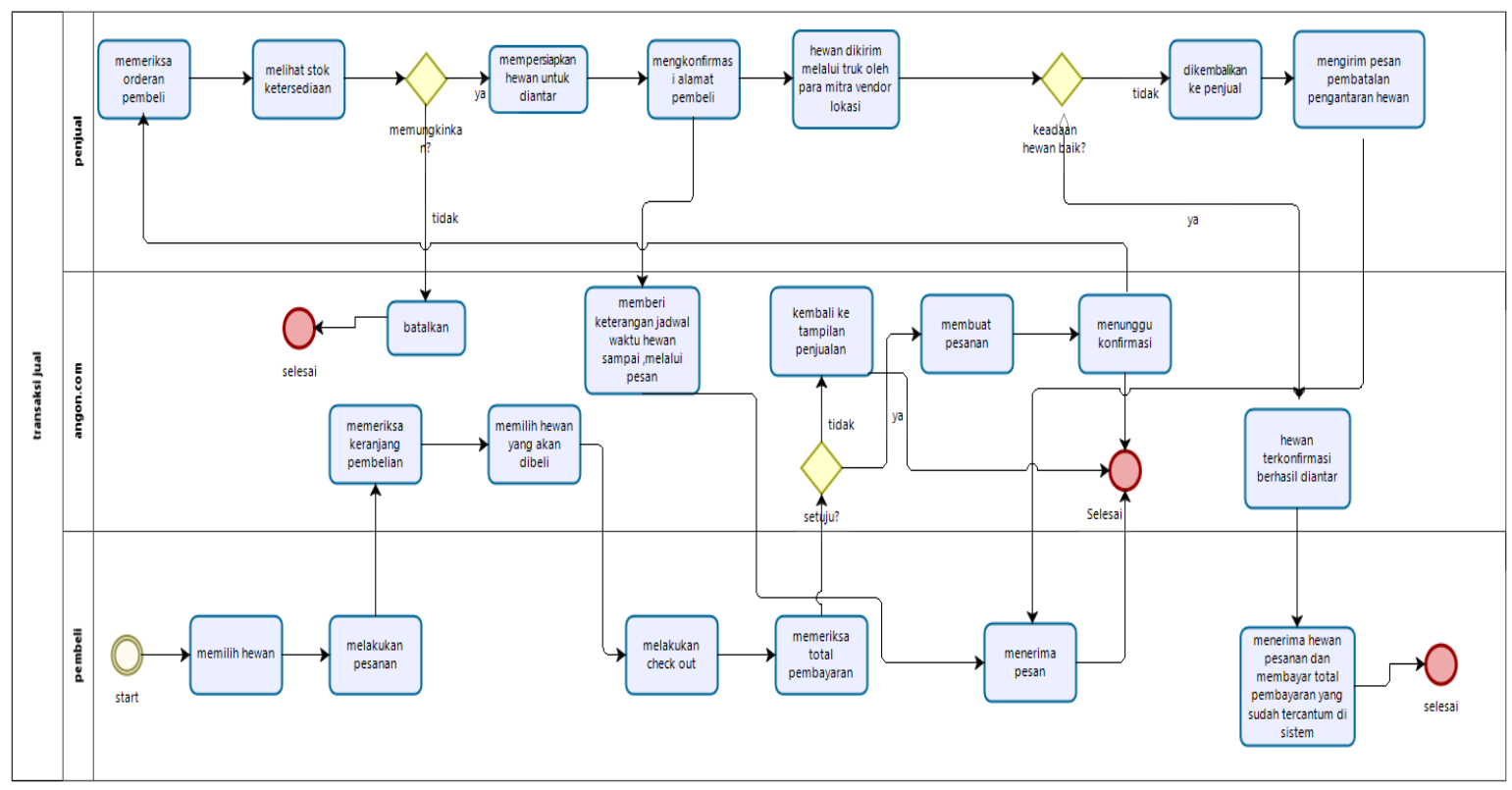

Gambar 3. Proses Transaksi Jual

Keterangan gambar 3.

1. Setelah pembeli sign up, maka pembeli bisa langsung melanjutkan aktifitasnya dengan memilih hewan yang diinginkan.

2. Lalu melakukan pesanan, dengan memilih hewan tersebut dan melihat tampilan data hewan berikut deskripsi yang telah diupload oleh penjual. Dan memasukannya ke keranjang pembelian untuk proses lebih lanjut.
3. Memeriksa kembali keranjang pembelian, dan memilih hewan yang akan dibeli di menu dalam keranjang.

4. Melakukan checkout, dan melihat detail total pembayaran.

5. Jika setuju, maka membuat pesanan dan menunggu konfirmasi penjual. Jika tidak, maka sistem akan otomatis beralih ke tampilan beranda penjualan.

6. Lalu, penjual mendapatkan notifikasi dan memeriksa pesanan pembeli. 
7. Melihat stok ketersediaan apakah ada atau tidaknya, dan hewan terjamin dalam keadaan segar.

8. "Memungkinkan", Jika iya maka langsung mempersiapkan hewan untuk diantar. Tetapi jika tidak, maka akan langsung di batalkan melalui sistem.

9. Sebelum diantar, maka terlebih dahulu memeriksa kembali alamat pemesan. Dan mengkonfirmasinya melalui SMS Sistem untuk keterangan jadwal waktu antar dan sampai.

10. Lalu pembeli, akan menerima pesan.

11. Dan penjual memberi hewan ternak ke vendor lokasi yang dimilikinya untuk diantarkan.

12. Di perjalanan, vendor memeriksa kembali keadaan hewan, Jika hewan tiba-tiba sakit atau mati, maka hewan diantar untuk dikembalikan ke penjual. Dan mengirim pesan pembatalan pengantaran hewan ke pembeli melalui sistem penjual. Tetapi jika, hewan baik-baik saja, maka akan mengkonfirmasi sistem bahwa hewan terkonfirmasi berhasil diantar.

13. Pembeli membayar total pembayaran ke vendor sesuai yang tertera di sistem dan menerima hewan ternak yang diinginkan.

\section{Perancangan Sistem}

Rancangan aplikasi marketplace merupakan rancangan perangkat lunak dibangun untuk membantu dunia bisnis dan keuntungan dalam pengelolaan proses memanajemen seperti proses kelola data, kelola hewan, kelola toko, kelola laporan, transaksi. Perancangan sistem menggunakan Unified Modeling Language (UML) (Hunt, 2000). Sistem yang akan dirancang akan memiliki fitur-fitur berikut ini guna menyesuaikan dengan fungsi kerja setiap aktornya.

1. Validasi Login

2. Setting Data Master

3. Sign Up Toko

4. Kelola Hewan

5. Sign Up Pembeli

6. Transaksi Jual

7. Kelola Laporan

Perancangan data yang digambarkan dengan use case merepresentasikan sebuah interaksi antara aktor dengan sistem. Gambar 4 berikut merupakan use case dari sistem yang dirancang.

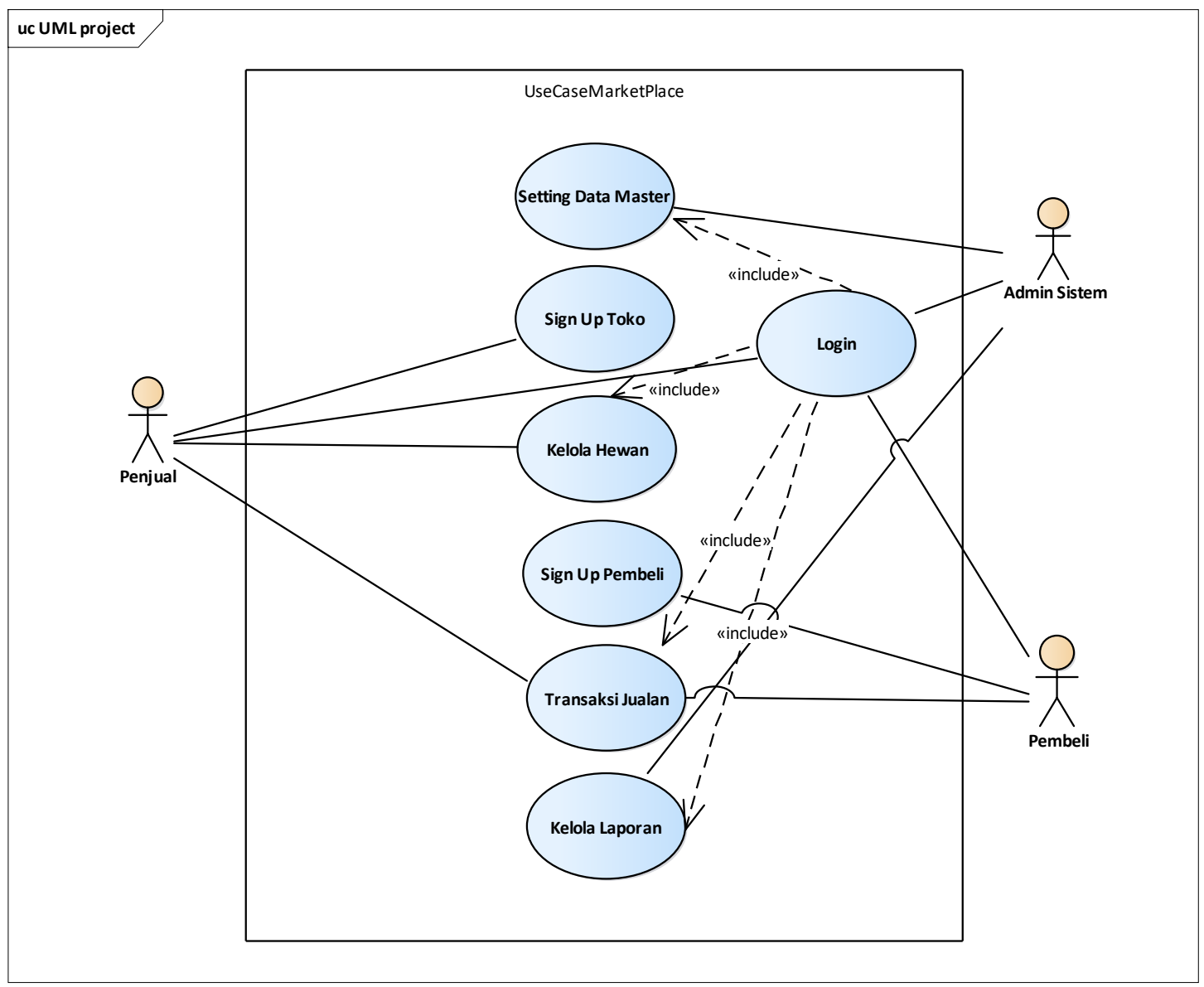

Gambar 3. Usecase Diagram Marketplace Application 
Sistem ini terdiri dari tiga aktor yaitu :

1. Admin Sistem

2. Penjual

3. Pembeli

Berikut ini adalah desain basis data yang akan dibangun untuk MarketPlace Hewan Ternak Application yang secara garis besar menggunakan table-tabel berikut sesuai dengan pemodelannya pada class diagram dan model data seperti disajikan pada tabel 1 dan gambar 5 .

Tabel 1. Daftar Rancangan Tabel pada Aplikasi

\begin{tabular}{|c|l|l|l|}
\hline No & \multicolumn{1}{|c|}{$\begin{array}{c}\text { Nama } \\
\text { Tabel }\end{array}$} & \multicolumn{1}{|c|}{ Jenis } & \multicolumn{1}{|c|}{ Primary Key } \\
\hline 1. & $\begin{array}{l}\text { Data } \\
\text { Master }\end{array}$ & $\begin{array}{l}\text { Tabel Admin } \\
\text { Sistem }\end{array}$ & $\begin{array}{l}\text { Kode Admin } \\
\text { Sistem }\end{array}$ \\
\hline 2. & Pembeli & Tabel Pembeli & Kode Pembeli \\
\hline
\end{tabular}

\begin{tabular}{|c|l|l|l|}
\hline 3. & Penjual & Tabel Toko & Kode Toko \\
\hline 4. & Hewan & Tabel Hewan & Kode hewan \\
\hline 5. & Transaksi & Tabel Transaksi & Kode Transaksi \\
\hline 6. & Agreement & Tabel Agreement & Kode Agreement \\
\hline 7. & Laporan & Tabel Laporan & Kode Laporan \\
\hline
\end{tabular}

Perancangan antarmuka berisi semua perancangan tampilan pada marketplace hewan ternak application yang terdiri dari tiga pengguna. Pengguna pertama adalah Admin Sistem yang melakukan pengelolaan data aktivitas yang berjalan di aplikasi, data pengguna sistem. Kedua adalah Penjual yang melakukan aktivitas penjualan dan melakukan masukan produk hewan di toko. Ketiga adalah Pembeli yang menerima tagihan berupa total pembayaran transaksi.

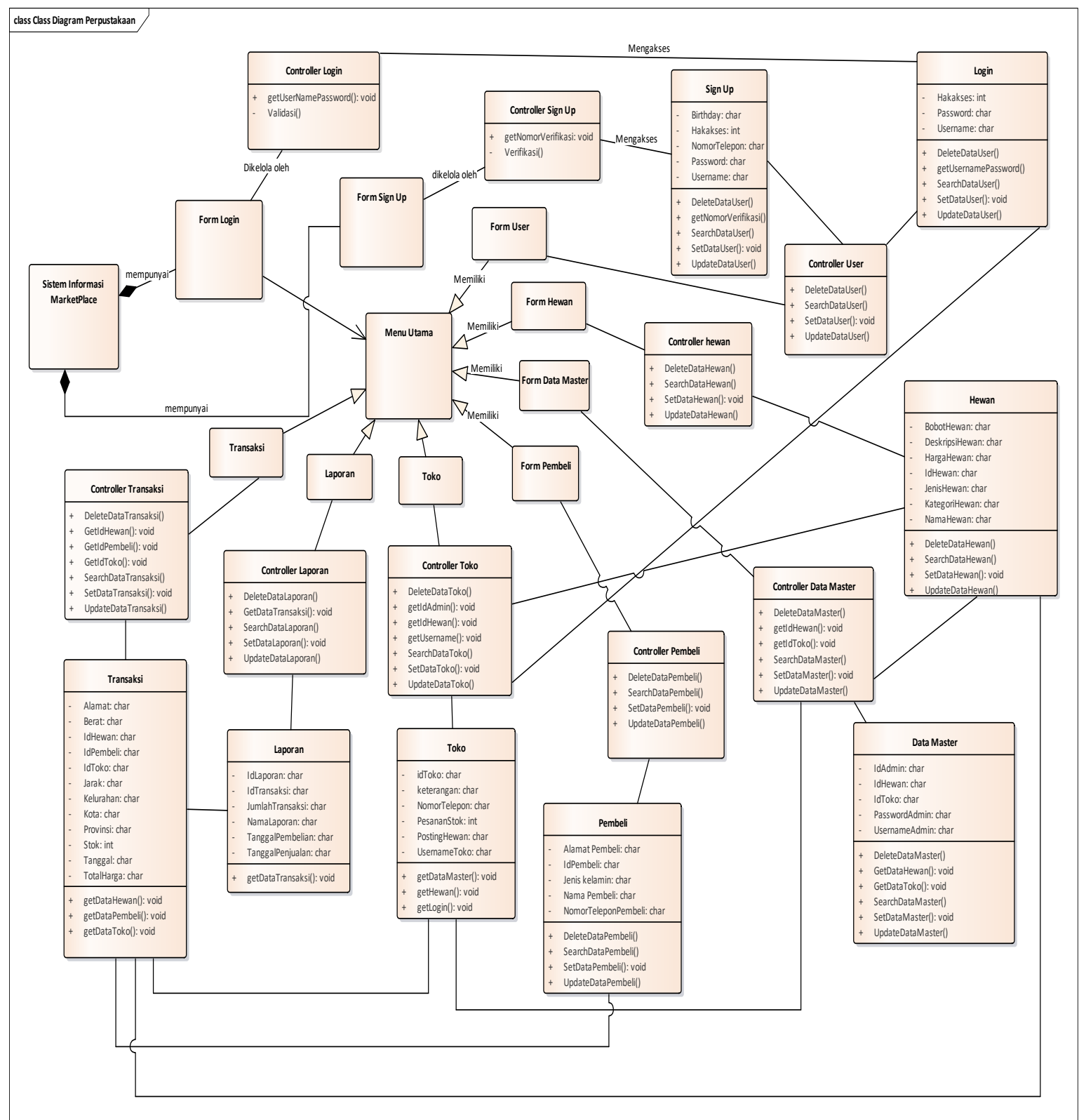

Gambar 5. Class Diagram Marketplace Application 
Perancangan halaman awal admin sistem ditampilkan pada gambar 6 berikut:

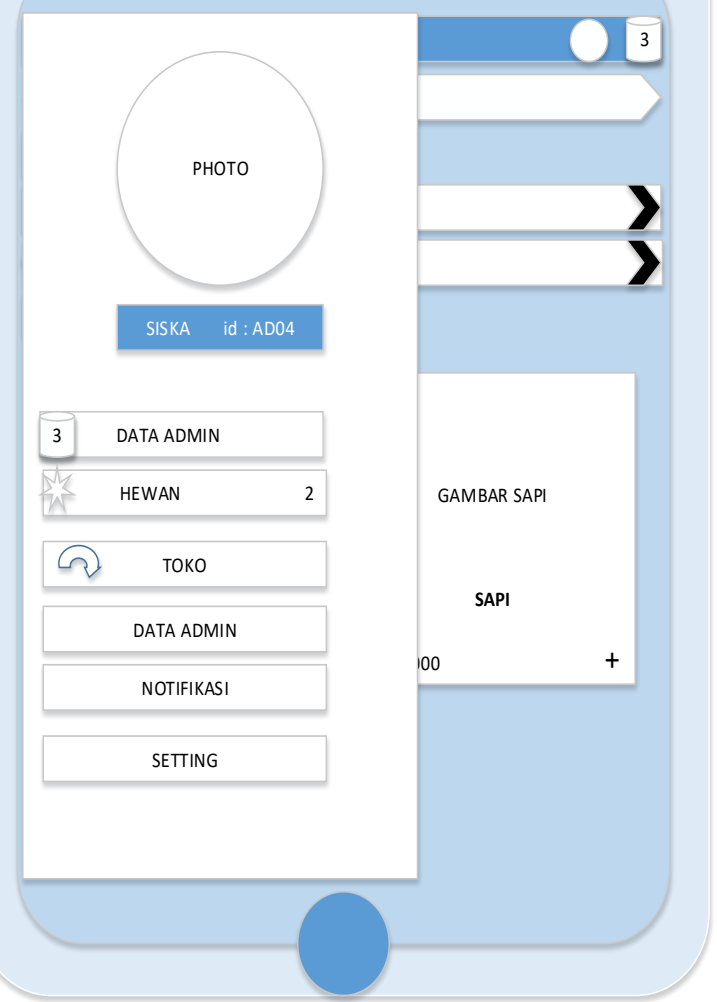

Gambar 6. Rancangan Halaman Awal Admin Sistem

\section{KESIMPULAN}

Kesimpulan dari penelitian rancangan marketplace application yang dilakukan adalah telah terdefinisi proses bisnis Aplikasi marketplace yang selama ini berjalan dan terdapat peluang untuk merancang media komunikasi dan jual beli antara toko, penjual dan pembeli. Rancangan marketplace application yang dihasilkan didasari dari proses bisnis yang berjalan, arsitektur aplikasi dan dokumentasi kebutuhan fungsional yang formal, memberikan kontribusi berupa arsitektur aplikasi yang dapat dijadikan arahan merealisasikan aplikasi dengan menerapkan rancangan teknologi informasi. Pada tahapan analisis pemodelan yang digunakan menggunakan BPMN, sedangkan pada tahapan perancangan menggunakan UML.

\section{SARAN}

Pada penelitian berikutnya disarankan untuk mengimplementasikan rancangan aplikasi marketplace berbasis android dan mengevaluasi kembali untuk penambahan fitur pendukung pengambilan keputusan.

\section{UCAPAN TERIMA KASIH}

Penulis mengucapkan terima kasih kepada Politeknik Pos Indonesia yang telah memberi dukungan financial terhadap penelitian ini.

\section{DAFTAR PUSTAKA}

Barnes, D. (2001). Understanding Business: Processes. New York: Routledge.

Donoriyanto, D. S. (2010). Analisis Kualitas Pelayanan Jasa Pengiriman Barang Dengan Metode SERVQUAL dan QFD di PT. APAS. Jurnal Tekmapro.

Hafidh. (2020). Bisnis Melalui Online Marketplace, ketahui Kelebihan dan kekurangannya. Retrieved from Jurnal Entrepreneur website: https://www.jurnal.id/

Hunt, J. (2000). The Unified Process for Practitioners: Object-oriented Design, UML and Java. London: Springer.

Hutabarat, M. R. S., Sarkis, I. M., \& Manurung, S. (2018). PENERAPAN KONSEP C TO C DALAM MEMBUAT WEB SITE MARKETPLACE PENJUALAN KERAJINAN TANGAN. Majalah Ilmiah METHODA, 8(3), 65-72.

Hutauruk, B. D., Naibaho, J. F., \& Rumahorbo, B. (2017). Analisis dan Perancangan Aplikasi Marketplace Cinderamata khas Batak Berbasis Android. Jurnal Methodika, 3(1), 242-246.

Pangestu, D. A. (2019). ANALISIS STRATEGI PENGEMBANGAN RANTAI NILAI (VALUE CHAIN) KOMODITAS NANAS MADU DI KECAMATAN KASOMALANG KABUPATEN SUBANG. Bandung.

Pateman, H., Cahoon, S., \& Chen, S. L. (2016). The Role and Value of Collaboration in the Logistics Industry: An Empirical Study in Australia. Asian Journal of Shipping and Logistics, 32(1), 33-40.

https://doi.org/10.1016/j.ajsl.2016.03.004

Porter, M. E. (1985). Competitive Advantage: Creating and Sustaining Superior Performance. New York: Simon and Schuster.

Rusdiana, H. A. (2014). Manajemen Operasi (I; B. A. Saebani, Ed.). Bandung: CV Pustaka Setia.

Saraswati, A., Baihaqi, I., \& Anggrahini, D. (2017). Membangun Supply Chain Resilience dengan Pendekatan Quality Function Development: Studi Kasus Perusahaan Freight Forwarder. Jurnal Sains \& Seni ITS, 6(2), 273-276. 
Solusi E-Commerce. (2019). Strategi Menjajakan Produk di Marketplace. Retrieved from SIRCLO website: https://www.sirclo.com/

Supratman, J. (2014). PERENCANAAN OPTIMASI PRODUKSI PRODUK FREEZER DAN

SHOWCASE DI PT FPS. Jurnal PASTI, X(3), 320-341. 